ERATO 合原複雑数理モデルプロジェクト中間評価報告書

研究総括 :

合原一幸【東京大学生産技術研究所／教授】

研究体制 :

複雑数理解析グループ （東京大学駒場オープンラボラトリー）

複雑生命情報グループ（東京大学駒場オープンラボラトリー）

複雑系計算グループ（東京大学生産技術研究所）

評価委員（あいうえお順、○は主査）：

秋山 泰【【産業技術総合研究所生命情報科学研究センター/センター長】

○大石 進一【早稲田大学理工学術院／教授】

樺島 祥介【東京工業大学大学院総合理工学研究科／教授】

斎藤 利通【法政大学工学部/教授】

斎藤 成也【国立遺伝学研究所／教授】

総合評価 : 秀（Excellent）

1. 評価の概要

もともとギリシャ語に起源する英単語 chaos（カオス）は、一般用語としては「混 沌」と訳される。一方、科学技術の分野では決定論的力オス、言い換えると「決定論的 な力学系に支配されながらも、混沌とも呼べる複雑な挙動を示す」力学現象のことを指 す。自然界の広い範囲にカオス現象が存在し、そして、非常に豊かな構造の存在が示さ れてきた。従来複雑でかつ予測不可能と思われていた現象でも、これがカオス現象であ ることが洞察できるならば、「混沌」と思われていた現象であっても、我々が予測した り制御したりすることが出来るのではないかと期待されているのが、カオスが注目され ている所以でもある。

合原一幸・東京大学生産技術研究所教授を研究総括（以下、総括と略す）とする 「ERATO 合原複雑数理モデルプロジェクト」では、非線形科学や総括の提唱による「カ オス工学」をもとに、世の中に実在するさまざまな複雑なシステムを普遍的に記述する 数理モデリングの基礎理論を構築し、これを個別の実在システムに適用したモデル作成 を行う。そして、これらのアウトプットを双方向でフィードバックしあうことによって、 
「普遍性」を有しかつ複雑なシステムに適用可能な「個別性」を兼ね備えた複雑数理モ デリング理論を体系化することを目的としている。プロジェクトは 2003 年 11 月に発足 した。研究の柱は

(i) 複䧱数理モデリングの理論構築、

（ii）遺伝子・タンパク質ネットワークやニューラルネットワークなどの生命情報ネッ トワークの動的情報処理原理の解明、

（iii）複雑系コンピューティングの理論と実装技術の開発、

（iv）新興感染症（例えば新型インフルエンザ）の予測や防御および前立腺癌の数理モ デル化とその治療への応用

等である。そして、その総合として「複雑系で計算する」新しい情報処理技術の確立を 目指し、戦略目標「新しい原理による高速大容量情報処理技術の構築」に資する研究取 り組みがなされている。

合原総括は、上記のような目標設定から、自身の本務先である東京大学生産技術研 究所がある東京大学駒場リサーチキャンパス内に、3つの研究グループ（複雑数理解析 グループ、複雑生命情報グループ、複雑系計算グループ: 総勢約 25 名の構成員）を設 けている。また、(ERATOの趣旨でもある) グループの垣根にとらわれない運営を行い、 大きく分けて 5 つの研究テーマー（1）複雑モデル基礎論、（2）脳・神経システム、(3) 細胞システム、（4）複雑系コンピューティング、（5）疾患の数理モデル 一が平行して 走っている。研究員らは各々の研究を主体的に行うことはもちろんであるが、毎週 1 回 の全体ミーティングや公開セミナー ${ }^{\mathrm{a}}$ 、国際ワークショップ ${ }^{\mathrm{b}}$ にって、自らが研鑽さ れる機会に浴している。プロジェクト発足後約 3 年が経過した現時点で、既に複数の研 究員が国内外の大学機関に然るべきポジションを獲得していることは、まさにこうした ことが少なからず反映されていると言えるであろう。また、同プロジェクトを特徴づけ るものとして、約 10 の研究グループとの協力関係が挙げられる。これは、研究員に対 して研究上のコミュニケーションの機会を多く持たせるという配慮がなされた運営状 態であると言える。数理研究は、本来個人を主体として行うと見なされがちであるが、 より広範な分野での普遍的な複雑数理モデリングの確立を目指すことが本プロジェク トの特質であるといえる。こうした連携関係が効果的な調和をもたらしていることは、 現在までの研究成果からもうかがえる。以上の点から、合原総括の指導力やリーダーシ ップは高く評価されるべきものであろう。

さて、我々 5 名の評価委員は、事前にプロジェクトから配布された資料や論文を査 読した上で、2006 年 11 月 18 日に東京大学生産技術研究所にてヒヤリング形式の中間

\footnotetext{
a プロジェクトからの報告によると、2006 年 10 月までに総計 72 回（うち 23 回は外国人による講演）のセ ミナーが開催されている。

b International Symposium on Complexity Modelling and its Applications (2004)、International Workshop on Gene-Protein Dynamics of Circadian ClocksおよびInternational Symposium on Complexity Modelling and its Applications (2005)、International Workshop on Synchronization: Phenomena and Analyses (2006)の計 4 件は、本 ERATOプロジェクトが主催したものである（共催：東京大学 21 世紀COE「情報科学技術戦略コア」）。
} 
評価会を開催した（合原総括やグループリーダーらに対して）。個々のテーマへの詳細 な評価は次章に述べるとするが、現在までに、特に「複雑モデル基礎論」や「脳・神経 システム」を中心として秀でた成果が上がっており、高い評価に至らしめるものである。 一方で、残る約 2 年の研究期間でより大きなアウトプットをもたらし、約 5 年間の ERATO プロジェクトとしての「今後の新しい科学技術の芽を生み出す」ための提言を 与えるとするならば、その 1 つとしは、現在までの成果からより大きな波及性を生み 出せるか（いかに実用へと繋がるような手がかりを見出すか）ということである。「複 雑モデル基礎論」では、それは例えば適用範囲が明確でユーザフレンドリな分岐現象解 析ツール（ソフトウェア）の開発であり、「複雑系コンピューティング」では、実装技 術のみならず数理モデルの導出そのものである。また「細胞システム」では、ウェット な生物学実験との対比であり、研究が生物学の一部分であると認知されるような深化で ある。さらに「疾患の数理モデル」では、複雑系モデリングの医療への貢献の顕著な適 用例を示すことである。個々の研究テーマや研究課題のさらなる追究と、プロジェクト 全体としての方向性のバランスを考えながら、「これがプロジェクトの最大の目玉だ」 と言うものを 1 つでも多く発信できるような研究戦略を、今後として期待したい。

\section{2. 評価の詳細}

\section{（1）複雑モデル基礎論}

本テーマは、単純な要素に分割して法則を線形化して理解するという従来科学の基 本的な方法論を乗り越える、新しい科学的な方法論を与えようとするものである。それ により脳・神経システムや細胞システムなどのターゲットに切り込むことを目標として いる。具体的には一（i）さまざまな力学系の呈する分岐現象を系統的に解析するツー ルの開発（「分岐解析」）、（ii）複雑系の挙動を理解するための特徵抽出を目指した「非 線形時系列解析」、（iii）「情報数理解析」によるモデリングを行っている。

（i）「分岐解析」については、変分方程式を自動的に生成する機構を実装し、分岐 集合の系統的で精密な計算を可能にしている。また、可視化に優れたユーザインタフェ ースを有するソフトウェアを開発し、理工系の汎用シミュレーションソフトウェアの一 つである MATLAB 上に実装している。これらの成果は、分岐解析の標準解析ソフトウ エアツールの確立に結びつくものとして高く評価したい。すなわち、非線形システムの 分岐現象に関連する具体的な問題の解析ソフトウェアツールが、ユーザフレンドリなイ ンタフェースを持つように意識的に構築されて、活用されている。このツールは「分岐 解析の標準解析ソフトウェアツール」として将来一般の研究者もユニバーサルに利用可 能なソフトウェアツールに発展し得るものと予想され、大変好感が持てる。今後に対し て提言を与えるならば、1）クラスター化、グリッド化等、大規模計算用へと発展させ 
る方向性、2）ツールの適用範囲をより明確にしつつ、その分野の決定的なシミュレー ションツールとする、等が考えられる。いずれにしても、MATLAB 上の汎用ツールボ ックスとして完成度を高めることで、力学系理論による複雑系モデリングのための基本 的ツールの一つとなることが期待されるので、今後の研究戦略に期待したい。

(ii)「非線形時系列解析」については、時系列データの特徽抽出のために、カーネ ル正準相関分析法と同方向性リカレンスプロット法を応用している。カーネル正準相関 分析法においては 2 素子からなるカオス力学系の結合系に関する一般化同期現象 (GS) cに着目し、GS状態における非線形な相関を確認する方法を提案した。今後は異常検出 など実データの解析などの実践上での有用性を検証する必要があると思われる。以上の 成果は、既存法を非線形性が強い場合にも柔軟に対応できる形に持ち込んだものとみな すことができ、低次元特徵量抽出とその精密解析を可能にすると思われる。

（iii）「情報数理解析」については、情報量が制約された条件の下で推定誤差を有界 に抑えることができる効率的な符号化法を提案した。今後においては、より複雑な系への展開 を図り、センサーネットなどへの活用などへの展開を期待したい。

複雑数理の「普遍性」に関する着眼を有効活用し、生命システムやコンピューティ ングといった「個別性」を解き明かそうという、本テーマの全体レベルは、総括の長年 にわたる研究成果に裏付けられてもおり、国際的に見ても十分に高く、その達成状況は 秀でていると評価できる。残る研究期間の取り組みにおいては、先にも述べたように、 特に「分岐解析」におけるソフトウェア開発への期待が高く、他の研究者にとって共通 の研究プラットフォームとなって欲しいというのが、評価委員の一致した意見である。

(2) 脳・神経システム

ヒトの脳は 10 の 11 乗個とも言われる神経細胞（ニューロン）が織りなす精緻なネ ットワーク構造からなり、本プロジェクトの看板でもある「複雑性」が登場する顕著な システムである。脳の情報処理原理や情報コーディングを複雑数理モデルの立場から解 明するために、同テーマでは一（i）ニューロンの性質からネットワークの挙動を調べ ると同時に、(ii) ニューラルネットワークと脳を現象や機能の視点から比較することに より、ネットワークの構造やニューロンの性質を理解する一という 2 つアアプローチを 取り研究が進められている。

（i）においては、単一ニューロンの詳細な分岐解析を進めるとともに、ニューロ ン間での電気的結合や化学的GABA性シナプス結合がネットワーク同期現象に与える 影響を明らかにした。また、シナプス結合の抑制性や興奮性などの性質をニューロンの

\footnotetext{
${ }^{\mathrm{c}}$ Generalized Synchronizationの略。結合によって 2 つのダイナミクスの間に非線形関数関係が生成され、系 全体の運動の実効自由度が制限されることを表す。
} 
数理モデルによって詳細に検討している。さらに、シナプス強度 ${ }^{\mathrm{d}}$ の Hebb ${ }^{\mathrm{e}}$ 的可塑性お よびPoisson発火細胞 $\mathrm{f}$ に対する発火率依存性・恒常的可塑性を数理的に理解するための 知見を与えた。また（ii）においては、電気的結合を持つニューラルネットワークモデ ルを構築し、その振る舞いをカオス的遍歴の観点から考察している。その結果、同期状 態では発火タイミング符号化による情報伝達が優位であり、非同期状態では集団発火率 符号化による情報伝達が優位であることを示している。

上記の成果は本プロジェクトのアクティビティの高さを示す一例であり、全体とし て、ニューロンおよびニューラルネットワークの挙動の包括的理解に対する数理的解析 の有用性を指し示寸ものとして、高い評価に至らしめる。それは国際的にも同じく評価 されているところである。これらは、合原総括の故 松本元博士とのヤリイカ巨大神経 軸索のカオスダイナミクス解明に端を発する研究実績の積み上げが遺憾なく発揮され ていることの表れでもあろう。引き続いての研究取り組みに期待したい。

（3）細胞システム

細胞は生物を構成する基本単位であると同時に、それ自体が高度に統合されたシス テムである。生命を理解するには、非線形系である細胞内および細胞集団のダイナミク スを解き明かすことが極めて重要である。本テーマではこうした問題意識から、「細胞 内システムのモデル論」「生命リズムのモデル論」「細胞集団システムのモデル論」の 立場から研究を進めている。

その中でも「生命リズムのモデル論」は、実験的知見と数理研究との関連づけが行 われている成果として、高く評価できると言える。特に生物の概日リズムに焦点をあて、 分子遺伝学・分子生物学的手法により解明された、生物時計の分子機構に関する知見に 基づき数理モデルを構築し、分岐理論を応用した数值解析手法を開発することによって、 光入力の遺伝子タンパク質ダイナミクスに及ぼす影響に特徵的な振る舞いを示すこと を指摘している。また、数理モデルによって概日リズムの振動解を得るとともに、工学 的にショウジョウバエ培養細胞に対してキメラ遺伝子群を導入し、振動が生じることな

\footnotetext{
$\mathrm{d}$ ニューロンにより生成された神経スパイクが、シナプス結合を通して他のニューロンの膜電位に与える 影響の大きさのことを指し、ニューロンの活動に依存して変化することが知られている（シナプスの可塑 性)。

e カナダの心理学者Donald Olding Hebbが 1949 年に著した「The Organization of Behavior」において、「同 時に発火したニューロン間のシナプス結合は強められる」ことを主張している。

$\mathrm{f}$ 各細胞は、過去の発火の履歴とは無関係に、入力に応じた確率でスパイクを生成する。入力が一定であ るときには、スパイク間隔は指数分布に従い、一定時間内におけるスパイク数はPoisson分布に従う。

$\mathrm{g}$ ほ乳類においては、脳の視交叉上核（左右の視神経が交叉するところの上部にある神経核; 英語では “Suprachiasmatic nucleus (SCN)”) に体内時計が存在し、その発振機構は、時計遺伝子のネガティブ・フィ ードバック制御にある。
} 
どの検証を行うことで、数理モデルの妥当性を明らかにした。このような取り組みは、 従来の生物科学に数理モデルという概念を導入することで、実験的知見に信頼性を追加 しうるものとして、今後さらなる成果の発信に期待したい。一方、残る「細胞内システ ムのモデル論」、細胞集団システムのモデル論」についても数理的成果は着実に上がっ ているが、生物学としての研究と見なされる場合の、実験との対比や整合性の確認、デ ータの蓄積等研究の深化は、今後の重要課題であると言えよう。

従来の生物学と数理工学との分野融合により、新たな価值観を創造しようとする本 研究テーマのような学際性のあるものは、往々にしてチャレンジングであるが故に、(あ くまでも一般論として）どのような研究哲学を貫くかという設定が難しい。確かに、「融 合領域だからこそその領域なりの自由な発想で」というスタンスがないと、新たな領域 などは切り開けないが、一方で関連するどちらかの分野の厳しい価值観に触れることな くしては、その融合領域としての学問的な厚みは生まれてこない。合原総括らの研究戦 略によって、さらに意味のある大きな果実が得られることを期待したい。

（4）複雑系コンピューティング

本テーマでは一(i)さまざまな非線形ダイナミクスを生成する電子回路の合成、(ii) 物理現象による実数計算、（iii）数理モデルに基づくニューロン回路の設計一に関する 研究を行い、新しい複雑系計算装置の開発を目指寸ものである。

（i）非線形ダイナミクス生成回路の合成では、ディジタル回路で生成した時間波 形にパルス幅制御に基づく電流サンプリングを施し、任意の非線形関数を合成している。 同手法は従来法に比べ、チップ化とプログラム化に適しており、さまざまなアナログ回 路合成技術の展開に期待したい。

(ii） Floating-Gate MOSFET を用いたインバータ回路において、ゲートの電荷を一 瞬でリセットする仕組みを埋め込んでいる。これによって、従来のような寄生電荷放電 の前処理の必要が無くなり、ロバストで多彩なダイナミクスの実現を可能にしている。 汎用性と発展性のある優れた技術である。

(iii）シリコンニューロン回路の非線形数理モデルに基づく設計手法を構築してい る。これによって、回路構成やそのパラメータ調節が簡素化され、柔軟で汎用性のある 回路合成を可能としている。この回路は、ニューロンの情報処理機能の解明や、関連す る各種応用技術の研究の発展に貢献すると思われる。アナログ IC を用いて神経情報処 理機能解明を目指寸斬新な研究である。従来、アナログ IC は理論研究の補助的立場と みられることが多かった。

アナログ LSI の基本回路設計などでプロジェクト発足以前から積み上げてきた知 
見をもとに、同テーマで進められている高い回路技術の先端性は、高く評価される点で あると言える。プロジェクトからの報告によると、数理モデル論を専門とする研究員を 最近補充したことを伺った。これにより、プロジェクト全体の根底にある「複雑系で計 算する」というコンセプトについて、実装技術面に偏らず、数理的アプローチを含む、 より多様な角度から豊かな成果を出されることを期待したい。他のテーマでの人的リソ ースとのバランスの点から、あるいは約 5 年間のプロジェクト期間の中での方向性の観 点からも、目標設定の明確化を踏まえた検討作業が、今後必要となるかも知れない。

\section{（5）疾患の数理モデル}

感染症の流行・伝播や現代病と呼ばれるような疾患については、それらを回避する ための予防法や効果的な治療法が確立されることが強く要望されている。ここでは、効 果的に複雑系の解析手法を応用することにより、一般的に関心の高い医学および社会シ ステム分野における疾患の数理モデル研究をテーマとして扱っている。具体的には一

(i) 現代疾患（前立腺癌、ポケモンてんかん $\mathrm{h}$ 、コンビニ症候群）の数理モデル、 感染症（SARSや新型インフルエンザ）の伝播ダイナミクスーに取り組んでいる。

前立腺癌の数理モデル研究においては、PSA值 ${ }^{\mathrm{i}}$ をモニタしながら投薬・非投薬状 態の切り替えを行う間欠的内分泌治療下での癌の成長をハイブリッドシステムとして モデル化し、数值実験により、継続療法では再燃が起きるが、間欠療法では再燃が回避 される場合があることを明らかにしている。これは、治療計画の力学系的なモデルを構 築し、その分岐構造の解明から明らかすることにより達成されている。そして、間欠療 法において、より効果的なPSA基準值の設定方法について考察し、投薬・非投薬の切り 替えを適切に設定することにより、再燃のリスクを減らせることを数理モデル上で示し ている。

感染症（SARS や新型インフルエンザ）の伝播ダイナミクスの解明に関しては、ど の程度の精度で数理モデルに落とし込むかというところに慎重さを要する。プロジェク トでは、社会的なインパクトの高さに鑑み、ミクロな要素を十分に取り込み、モデルの 適用性を明確にして、学術的にも信頼性を最重視したかたちで進められていると感じら れた。医療研究機関との協力もなされており、双方向のインタラクションは、今後も緊 密であることが望ましい。

\footnotetext{
${ }^{\mathrm{h}} 1997$ 年に、アニメ番組「ポケットモンスター」での赤と青が点滅する映像により、視聴者が次々と発作 を起こし、全国で約 700 人が医療機関で診察を受けると言った社会問題が生じた。

${ }^{\mathrm{i}}$ Prostate Specific Antigen（前立腺特異抗原）の略称。PSAのごく一部分が血液の中に漏れ出て、血液検查で 測定することができる。血液の中に漏れ出るPSAの量は前立腺疾患（前立腺癌、前立腺肥大症、前立腺炎） などの病気で増加する。この事を利用してPSAは前立腺癌早期発見のマーカーとして、さらには治療経過 を見るマーカーとして普及している。
} 
以上のような成果は、論文成果という意味ではこれからであろうが、扱っているテ 一マの社会的重要度が高いことから、複雑数理の研究者がこれらの難題にチャレンジし ていること自体を高く評価すべきである。「医療に役に立つ予測ができるか」というこ とを視野に入れつつ、成果や広報の効果的発信により、多くの研究者・研究グループを 触発し、数理研究の真価を打ち出して欲しい。

以上 